\title{
P 113
}

\section{メンタルヘルスに関連する要因の職種別特徵について}

○秋山 ひろみ 永田 頌史 三島 徳雄

（産業医科大学産業生態科学研究所精神保健学教室）

【目的】精神健康度について職種ごとの特徽を 検討する。

【対象および方法】 28 項目版 GHQ、主観的職場 快適度 (0〜100 点の Visual analogue scale)、 職業性ストレス簡易調査票からストレッサー及 びソーシャルサポートの質問項目、独自に作成 した職場環境についての質問からなる質問票を 作成し、某電器メーカー勤務者 2430 名を対象に 調査を行った。回収した 2296 名（男性 1935 名、 女性 342 名、不明 19 名、平均年齢 $44.1 \pm 10.4$ 歳、回収率 94.5\%) を分析対象とした。解析で は目的变数を GHQ 得点 (Goldberg 法) とし、性、 年齢、残業時間、物理的環境、付属施設（休欯 所・洗面·更衣施設)、量的質的労働負荷、身体 的労働負荷、裁量権、仕事の適合性、対人暮藤、 職場のサポート、を従属変数として職種毎に重 回帰分析を行った。その際、性別はダミー変数

（男性 1, 女性 0）とし、変数選択はStepwise 法 にて行った。職種は事務、設計、開発、技術職

(その他)、技能（組み立て）、技能（組み立て 以外)、営業、その他に分類した。解析には SAS R6. 12 を用いた。
【結果】職種毎の特徴を表 1 に示した。表には 選択された変数の標準偏回帰係数を表示した。

組み立て職では付属施設が、組み立て以外の 技能職では量的質的労働負荷が、設計職では裁 量権が、開発職とその他の技術職では仕事の適 合性が、事務職では物理的環境が、営業職では 年齢が最も強く精神健康度に影響を与えていた。

また、どの職種でも $\mathrm{GHQ}$ 得点と主観的快適度 得点には有意な相関がみられた。

【結語】職種により、精神健康度に影響を与え ている要因に違いがあった。職場でのメンタル ヘルスを考える場合、職種の特徽を考慮した対 忘が必要であることが考えられた。

主観的な快適度と精神健康度には強い関連が あり、快適職場づくり活動はメンタルヘルスの よい職場づくり活動ともなることが考えられた。

\begin{tabular}{|c|c|c|c|c|c|c|c|}
\hline & \multicolumn{2}{|c|}{ 技能 } & \multicolumn{3}{|c|}{ 技術 } & \multirow[t]{2}{*}{ 事務職 } & \multirow[t]{2}{*}{ 営手 } \\
\hline & 組み立て & 組み立以外 & 殾尌 & 開発 & その他 & & \\
\hline $\mathbf{N}$ & 680 & 603 & 218 & 124 & 236 & 332 & 61 \\
\hline 年岺 & -0.14 & -0.17 & -0.12 & & -0.13 & & -0.48 \\
\hline 性 & -0.15 & & & -0.20 & & & \\
\hline 物理環境 & -0.16 & -0.10 & & & & -0.26 & \\
\hline 付霞施教 & -0.17 & -0.08 & & & & & \\
\hline サポート & 0.11 & -0.08 & -0.20 & & -0.14 & -0.18 & -0.26 \\
\hline $\begin{array}{l}\text { 仕事の適合性 } \\
\text { 仕事の载-7権 }\end{array}$ & -0.13 & $\begin{array}{l}-0.18 \\
-0.12\end{array}$ & $\begin{array}{l}-0.18 \\
-0.32\end{array}$ & -0.39 & -0.25 & $\begin{array}{l}-0.11 \\
-013\end{array}$ & \\
\hline 青的算的負荷 & 0.15 & 0.20 & 0.15 & 0.16 & 0.20 & 0.20 & \\
\hline 対人䓥藤 & & & 0.15 & & & & 0.25 \\
\hline $\begin{array}{l}\text { 身体的萯荷 } \\
\text { 睡眠時間 }\end{array}$ & & & & 0.25 & & & \\
\hline 垡䊦時間 & & & 0.19 & 0.16 & 0.18 & & 0.32 \\
\hline R2 & 0.21 & 0.20 & 0.37 & 0.30 & 0.21 & 0.22 & 0.39 \\
\hline 快涪度 & $52.2 \pm 18.7$ & $55.0 \pm 18.9$ & $49.6 \pm 20.4$ & $49.8 \pm 18.8$ & $60.0 \pm 18.1$ & $60.0 \pm 18.8$ & $47.3 \pm 22.5$ \\
\hline GHQ得点 & $5.33 \pm 4.93$ & $4.34 \pm 4.60$ & $7.42 \pm 5.67$ & $7.00 \pm 5.66$ & $5.81 \pm 5.46$ & $5.43 \pm 4.97$ & $5.60 \pm 4.50$ \\
\hline $\begin{array}{l}\text { 快道度とGHQ得点 } \\
\text { の相関係数 }\end{array}$ & $-0.24^{*}$ & $-0.16^{*}$ & $-0.39^{*}$ & $-0.38^{*}$ & $-0.30^{*}$ & $-0.27^{*}$ & $-0.46^{*}$ \\
\hline
\end{tabular}

